The absence of all spiral sculpture, and the strong, arcuate, oblique plications or ribs are the chief points of distinction.

\title{
Abretia brasiliensis.
}

A. testa parva, elongata, polita, saturate castanea, infra suturam zona angusta flava ornata; anfr. 10, primi 2 subglobulares, cæteri plani, plicis longitudinalibus superne tuberculis flavidis terminatis, (in anfr. ultimis duobus 15, inferne obsoletis) instructi, haud spiraliter striati; anfr. ultimus brevis, subquadratus ; apertura parva, fusca ; columella brevissima.

Var. omnino flavida.

Long. 11 mill., diam. 3.

Hab. Botafogo Bay, Rio de Janeiro (3 fathoms, sandy mud). Collected by J. Macgillivray, Esq., during the voyage of the 'Rattlesnake.'

A very distinct species, at once recognized by the smallness of its size, the deep chestnut colour, with the yellow band below the suture, which tints the nodulous ends of the longitudinal ribs, and the shortness of the aperture and columella. There is no spiral furrow or depression below the suture.

XXIX.-On the French Species of the Genus Geomalacus. By D. F. Hernemann, President of the German Malacozoological Society, Frankfort-on-Maine.

Through Mr. T. A. Verkrüzen of London I received a small parcel of living Geomalacus maculosus, Allman, from Ireland; and having carefully examined these, I am now enabled critically to investigate the statement of several French authors that this genus not only occurs in France, but is there represented by various species.

English authors started an hypothesis that the animals, with the plants they live amongst (and which are only met with in the south-west of Ireland), were of Asturian or Spanish origin.

Although it had not been proved that Geomalacus does occur on the Pyrenean peninsula until Lucas von Heyden found one specimen in the Asturias, during his entomological journey in Spain in 1868, and forwarded it to Germany, the above hypothesis of British authors was nevertheless adopted in 1867 by the French malacologists Bourguignat and Mabille; and they even went to the length of taking as an established fact what had been proposed as a supposition only.

Geomalacus having thus been once established as of Spanish origin, its distribution must, according to the ideas of these authors, have taken place by way of France only. All at 
once they discovered consequently in the forest of Meudon, near Paris, what they wished to find, not only the traces of the migratory Geomalacus, but even three new or entirely unknown species, which were described by Mabille, in his monograph of this genus published in the 'Revue et Magasin de Zoologie,' 1867, p. 53, as Geomalacus Bourguignati, Paladilhianus, and Moitesserianus. From that time new species continued ever increasing, the names of which may as well be passed over in silence; and this fabrication attained an alarming extent in France. The statements were at first so positively made by our French contemporaries, that even the incredulous (including myself) almost believed in the existence of this genus in France; but those who with any attention read my short treatise in the 'Nachrichtsblatt der deutschen malacozoologischen Gesellschaft,' 1869, p. 165, entitled “Zur Kenntniss von Geomalacus," will readily see what serious doubts I entertained upon the subject. Our French neighbours did not favour us with any drawings of their new species, although they described the English drawings as "déplorables."

I had myself never before seen a live Geomalacus; neither could I obtain any French proofs, in spite of the pains I took for this purpose. It will therefore, I trust, be deemed excusable that I expressed doubts where I could not contradict by facts. But now, since I received the living Geomalacus and have had an opportunity of examining the animal, the question assumes a different aspect.

The French so-called species do not belong at all to Geomalacus; and those who may still entertain a doubt on this point need but inspect the drawings, which have since appeared in Baudon's 'Mémoire sur les Limaciens du département de l'Oise' (Beauvais, 1871), of Geomalacus Mabilli, Baudon, and G. hiemalis, Drouet. These drawings are excellent; and for this very reason we at once detect in them our old acquaintance Arion melanocephalus, Faure-Biguet, which likewise has lately been recognized as our common Arion empiricorum, Fér., in its younger state of growth, by Seibert (see 'Nachrichtsblatt der deut. mal. Ges.' December 1872).

These drawings of Baudon are alone sufficient entirely and effectually to upset at once the famous myth of a French Geomalacus. This genus has not as yet been discovered in France; and all the species described as French are in all probability not different from Arion empiricorum. I very much question whether the French authors have ever seen a living Geomalacus; and for their own justification I would deny the fact, because they could never otherwise have entertained the idea of turning a young Arion into a Geomalacus, although it 
is no wonder that, when once an erroneous generic designation had been given to a young Arion, the number of species could be most readily increased.

The substitution has doubtless been no easy task for Mabille in the composition of his monograph; but he must have formed for himself a totally different conception of the animal, which had hitherto been described by English authors only, though with sufficient distinctness. In his generic diagnosis Mabille states that the animal is ornamented with an infinite number ("d'une infinite") of minute black, yellow, golden, white or silvery dots, which, by the by, is by no means correct; and in his improved specific diagnosis he even amends the original English descriptions in so cool a manner that I am astonished that English malacologists should not have replied to it. Mabille says, in the same diagnosis, that the English draftsmen, instead of covering the body of this slug with a multitude of white dots, had contracted the same upon the wrinkles, and, to facilitate the labour, had united them into one single spot on the different wrinkles. And this he states to be the reason why the Geomalacus appeared to be a black animal with longitudinal white ridges or hillocks, which he says is quite incorrect!

This statement of itself suffices to convince us that Mabille has never seen a living Geomalacus; for what he supposes to be altogether incorrect is precisely the actual fact. The Geomalacus is not covered with white or yellow dots, but with actual longitudinal spots extending on the back of the animal over one or two of the wrinkles. These spots are even distributed on a black ground in such a manner that they might easily be counted; and the drawings of Allman (Andrews) are quite correct.

Mabille's description of the respiratory orifice as being considerably in front ("très-antérieur") corresponds admirably with that of a young Arion. The original diagnosis says, "a Limace (differt) situ anteriori spiraculi;" for in Limax the respiratory orifice is situated behind the middle of the mantle, and not in front of it.

Further, incorrect is Mabille's statement respecting the internal shell-namely, "Limacelle délicate, excessivement plate;" and,further, "Sa Limacelle mince comme une pellicule." The original diagnosis says "Testa solida;" and, indeed, its thickness attains almost a third of its length, and nearly the half of its breadth. The shell is consequently by no means "délicate," and much less "mince" or "plate," but actually very solid-in fact, as solid as we rarely meet with internal hells, to whatever genus they may belong.

Ann. \& Mag. N. Hist. Ser. 4. Vol. xi. 
It only remains for me to add a few words, in order to dispose of the remainder of Mabille's species, created only to swell the above-mentioned monograph. These are designated:-Geomalacus Andrewsi, Mabille; G. anguiformis, Morelet; and G. intermedius, Normand. Allman, Andrews, and others repeatedly name a white-spotted variety, the same which in my treatise "Ueber Geomalacus" (Malacozool. Blätter, 1873), with drawings, I called var. Allmanni, in contradistinction to the more frequently occurring yellow-spotted variety, which is the typical form. Andrews calls the white-spotted form simply "the white variety ;" and on this white variety (it should be whitespotted variety) Mabille writes as follows:- "Cette nouvelle espèce, que nous dédions à Monsieur William Andrews de Dublin, et que tous les auteurs Anglais ont confondue avec le maculosus, se distingue de cette espèce par un corps blanchâtre, parsemé d'une multitude de petits points noirâtres. C'est l'inverse chez l'espèce précédente (maculosus)." He evidently misconstrues the original meaning; and the result is the new species Andrewsi. Jeffreys, in his 'British Conchology,' says, "I suspect that the Limax anguiformis of Morelet (Moll. Port.) also belongs to the present genus, if, indeed, it is not the same species as ours." This simple notice suffices to settle the Geomalacus anguiformis, Morelet, whose specific diagnosis is any thing but improved by the all but useless drawing of Morelet. Finally, Normand ascribes to his Arion intermedius an internal shell; and thus we obtain a Geomalacus iniermedius, Normand.

It is to be regretted that the rubbish of synonymy is thus needlessly multiplied to an extraordinary degree by such ingenuity in creating new species and even new genera-on which head see other reports.

Frankfort-on-Maine, January 1873.

The preceding short treatise was sent to me by D. F. Heynemann, Esq., with a request to publish a translation of the same in the 'Annals,' if deemed of interest on this side of the Channel. Having consulted J. Gwyn Jeffreys, Esq., F.R.S., \&c., and obtained his affirmation on this point, I have much pleasure in submitting $\mathrm{Mr}$. Heynemann's discussion to British malacologists, and beg to observe that in translating Mr. Heynemann's report from the original German I have adhered as closely to the sense of his delineations as is consistent with clearness and intelligibleness, and must refer those who wish to read the original to the 'Malacozoologische Blätter,' where Mr. Heynemann's monograph on the genus Geomalacus will appear with drawings. 
I take this opportunity to state, in reference to my report in the 'Annals' for November 1872, that the white variety of Tectura testudinalis, Miull., of which I obtained many fine specimens in Iceland, is likewise met with on the North-British coasts; and, possessing seemingly as strong claims to varietal distinction as many other named varieties do, I trust my proposed designation may not be deemed inappropriate.

I may also call attention to a slight printing-error which occurred on page 373, viz. Punctura instead of Puncturella.

2 Ampton Place, W.C.

T. A. Verkrüzen.

XXX.-Description of Labaria hemisphærica, Gray, a new Species of Hexactinellid Sponge, with Observations on it and the Sarcohexactinellid Sponges generally. By H. J. Carter, F.R.S. \&c.

A the request of Dr. Gray I have examined Labaria hemispharica, the sponge sent by Dr. A. B. Meyer to the British Museum from Singapore ('Annals,' vol. xi. p. 235, March 1873); and the following is its general and microscopic description.

\section{Labaria hemispharica, Gray.}

Sponge sarcospiculous, hexactinellid, now dry and colourless. Cup-like, massive, hemispherical, convexo-concave. Sides thick, margin obtuse, round, slightly contracted, concavity shallow. Surface of interior even, uniform; that of the convexity or exterior the same, but interrupted here and there by the presence of linear spicules, which project microscopically in a line round the outer border of the margin, then disappear, leaving a plain convex surface, but reappear towards the lower third, where, gradually becoming longer and congregated into small tufts, they finally end in a large stem-like bundle, which on issuing from the base of the sponge is half an inch wide, and spreads out into a tassel two inches long. Vents? (see Obs.). General structure of the body chiefly composed of smooth nail-like spicules, with four-armed heads, of different sizes, varying from such as can be easily seen with the unassisted eye down to microscopic minuteness, all knit together by the nail-like shaft being directed inwards, and the crucial arms expanded and interweaving with each other horizontally; thus, with the largest spicules on the surface, and their arms bent a little inwards, the whole are bound down, as well over the concavity as over the convexity, into a firm basketwork with even exterior. Internal structure, as seen by transmitted light through the surface, cavernous or largely cancellous, with 


\section{$2 \mathrm{BHL}$ Biodiversity Heritage Library}

Heynemann, D F. 1873. "XXIX.-On the French species of the genus Geomalacus." The Annals and magazine of natural history; zoology, botany, and geology 11, 271-275. https://doi.org/10.1080/00222937308696812.

View This Item Online: https://www.biodiversitylibrary.org/item/81041

DOI: https://doi.org/10.1080/00222937308696812

Permalink: https://www.biodiversitylibrary.org/partpdf/62685

\section{Holding Institution}

Smithsonian Libraries

\section{Sponsored by}

Smithsonian

\section{Copyright \& Reuse}

Copyright Status: Public domain. The BHL considers that this work is no longer under copyright protection.

This document was created from content at the Biodiversity Heritage Library, the world's largest open access digital library for biodiversity literature and archives. Visit BHL at https://www.biodiversitylibrary.org. 